\title{
dossiê |e
}

DOI: 10.11606/issn.2318-8855.v6i6p199-223

\section{Who watches the Watchmen: os espaços do tempo nos quadrinhos ${ }^{1}$}

Roberta Quirino *

Resumo: O tempo é o protagonista invisível das histórias em quadrinhos. Através dele, a visão do leitor também se torna fundamental para que a narrativa siga seu curso. No entanto, a subjetividade desse olhar de quem folheia as páginas ilustradas é o que torna a experiência das histórias em quadrinhos muito particular a cada um que se aventura pelos quadros de cada história. Watchmen é uma obra que usa o tempo como ferramenta fundamental de sua estrutura narrativa e de sua lida com os personagens. Ao analisar esta graphic novel por meio de tempos históricos nela representados (termo usado no meio quadrinístico para designar um subgênero das histórias em quadrinhos de conteúdo e linguagem mais complexas e narrativas longas com começo, meio e fim), pretendo analisar a influência da Guerra Fria não só nesta obra, mas também no gênero de quadrinhos da década de 1980; e o conceito nietzschiano do eterno retorno no personagem Dr. Manhattan / Jon Osterman, que também servirá como base para o conceito de sincronia do tempo. A relação do personagem com os relógios também será um ponto abordado juntamente com a ideia de escatologia e paranoia nuclear coletiva da época representada a partir da visão da dupla Moore e Gibbons.

Palavras-Chave: História em Quadrinhos, Guerra Fria, Watchmen, Tempo, Relógio.

1 Agradeço às companheiras e aos companheiros do Laboratório de Estudos sobre o Brasil e o Sistema Mundial (LabMundi-FFLCH/USP) pelos debates que têm sido essenciais à minha formação e ao Prof. Dr. João Paulo Garrido Pimenta por ter me ensinado que compreender os múltiplos estratos de tempo é essencial para o estudo de história.

*Graduanda em História pela Faculdade de Filosofia Letras e Ciências Humanas (FFLCH), Universidade de São Paulo (USP). Contato: roberta.quirinop@gmail.com. 


\section{dossiê}

Roberta Quirino

\section{A linguagem das histórias em quadrinhos}

As histórias em quadrinhos já tiveram várias definições desde que surgiram como instrumento para contar histórias. Diversos estudiosos trazem definições sobre o papel específico das sarjetas neste tipo de narrativa. Will Eisner (2000) as define como arte sequencial; já Steve McCloud (2005, p. 9) nos traz uma definição um pouco mais completa, que coloca as $\mathrm{HQs}^{2}$ como “imagens pictóricas e outras justapostas em sequência deliberada destinadas a transmitir informações e/ou produzir uma resposta no espectador".

A partir desta premissa mais completa de McCloud, Kurowsky (2016, p. 19) analisa como as HQs quebram uma linearidade comum a outras mídias por meio do uso das sarjetas: espaços em branco entre os quadros que também têm uma função narrativa. Na imagem abaixo, por exemplo, podemos ver que a ação de ataque do personagem com o machado, no primeiro quadro nas mãos fica subentendida no espaço em branco de um quadro ao outro. No segundo quadro vemos somente a onomatopeia resultante do ataque:

2 HQ e seu plural HQs são as abreviações comumente usadas de história em quadrinhos. Estes termos também serão explorados no presente trabalho. 

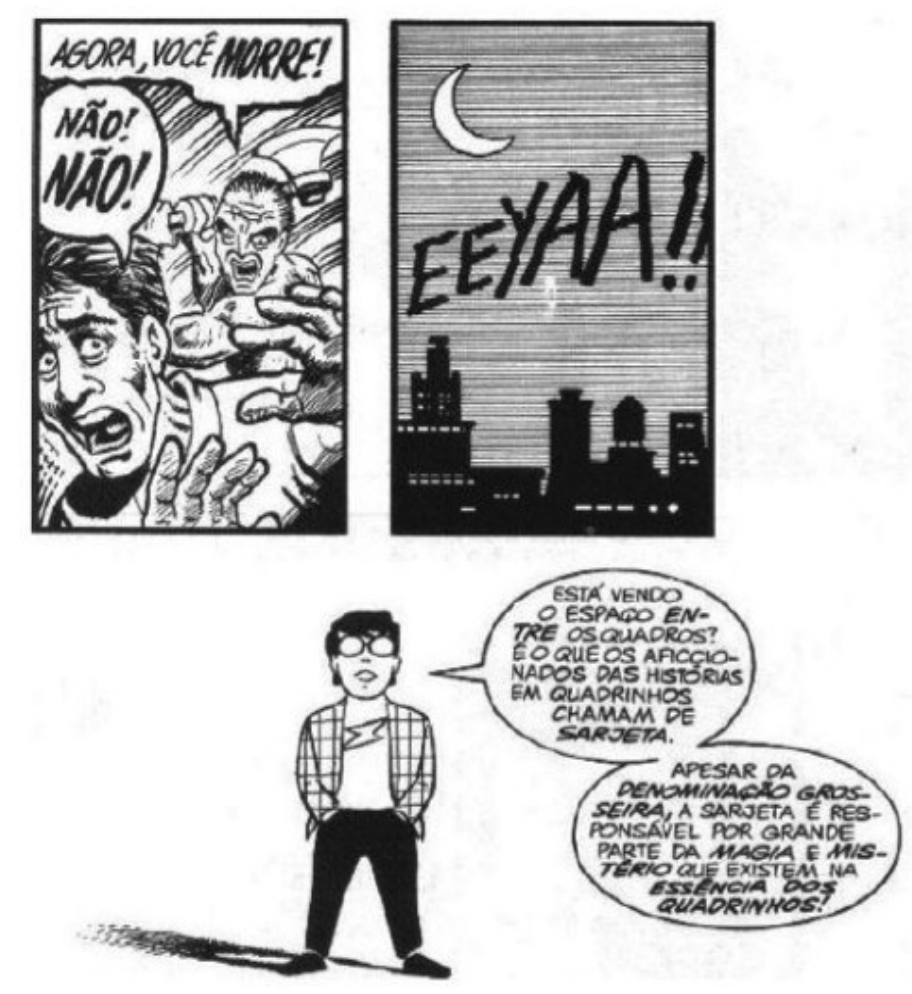

TM \& @ 2018 Mbooks

Imagem 1 - O que é a sarjeta, segundo Steve McCloud

Alexandre Linck Vargas (2015) também traz em sua tese de doutorado uma análise bastante abrangente sobre as sarjetas nas HQs. Ele coloca um importante debate sobre o papel destes espaços em branco entre os quadros seguem a visão de McCloud, citada acima, ou a enxergam de maneira mais funcionalista, como Thierry Groensteen. Sobre a visão deste pesquisador, Vargas ilustra (p. 279):

Deste modo, a sarjeta cumpriria, segundo Groensteen, somente a função (provisória) de anulação do quadro anterior, permitindo que o próximo exista como uma forma completa e compacta. "A 'sarjeta' entre dois quadros não é, portanto, o lugar de uma imagem virtual; é o sítio de uma articulação semântica, uma conversão lógica, de uma série de enunciáveis (os quadros) em uma indicação que é única e coerente (a história)". 
Roberta Quirino

Barbara Postema (2013) também expande a problemática sobre a função das sarjetas nas histórias em quadrinhos. A autora coloca que estes espaços entre os quadros compõem uma página ao lado das molduras (ou margens) e dos próprios quadros. Para a autora, toda a composição da página fornece "signos formais (...) oferecendo estrutura e ordem"; desta forma, "Ambas, sarjetas e margens, são elementos paratextuais dos quadrinhos, criando condições materiais para o texto dos quadrinhos, mas ao mesmo tempo, também significam por elas mesmas."

O uso das sarjetas, portanto, também faz parte da construção da narrativa, e o leitor se torna personagem principal neste processo porque parte dele a ação de construção dessa lacuna a partir de sua percepção sobre a história e o sentido que ela representa. Na imagem acima, não é mostrado o assassinato do personagem ameaçado por outro com um machado, mas somente seu grito no quadro seguinte; a sarjeta representa então o tempo do homicídio deste personagem, ato que foi completado pela nossa interpretação, enquanto leitores, da história contada.

O tempo do espaço em branco também faz parte da linguagem da história em quadrinhos, além das imagens e dos balões de fala. Assim como estes dois elementos, as sarjetas colaboram com a passagem do tempo que é contada nos quadros. Barnes (2009, p. 52) discorre sobre o papel do leitor neste processo e sua particularidade em relação a outras ferramentas:

Em particular, a arte sequencial se concentra nos incríveis mecanismos que o cérebro usa para costurar imagens sequenciais em uma experiência significativa da passagem do tempo (...) Em um quadrinho o movimento por meio do tempo é uma função controlada pelo espectador e não pelo editor. Leva tempo e o movimento literal dos olhos pelo espaço [dos quadros] para ler um quadrinho. As animações e o cinema produzem ilusões corporais de movimento, enquanto os quadrinhos colocam especial ênfase nas sensibilidades conceituais do leitor e capacidade de criar o encerramento [da narrativa]. (...) Quadros individuais geralmente ilustram um momento da narrativa, mas o tempo é criado na sarjeta. Lá, a imaginação humana junta duas imagens separadas e as transforma em uma única ideia. ${ }^{3}$

3 Tradução minha. No original: "In particular, serial art focuses on the amazing mechanisms the brain uses to sew 
Who watches the Watchmen: os espaços do tempo nos quadrinhos

Assim sendo, o tempo tem, independente de qual história a ser contada, um papel fundamental no andamento e na conclusão de todas as narrativas. Mais do que um espaço em branco, as sarjetas representam uma estrutura que faz parte da história e que tem, no leitor, ator principal para que este movimento funcione. Além disso, esses tempos também são usados como as formas que Alan Moore e Dave Gibbons pensavam o mundo em que viviam.

\section{A “Invasão Britânica” nos quadrinhos}

"All comics are political" (MOORE apud Sabin, 1993, p. 89). Esta frase ilustra bem como Moore entende e usa seu trabalho a partir das histórias em quadrinhos. Ao lado de nomes como Neil Gaiman, Grant Morrison, Peter Milligan, entre outros, o autor britânico dos expoentes da denominada "invasão britânica" nos quadrinhos. Este movimento se iniciou a partir da década de 1960 e influenciou, primeiramente, gêneros musicais como o pop e o rock para depois se expandir para outras áreas do entretenimento norte-americano. A, assim chamada, "onda" das HQs, iniciada na década de 1980, desejava se afastar das tradicionais histórias de super-heróis e criar histórias mais autorais, onde o escritor seria o principal responsável por conduzir as histórias e não o editor, que, no mercado norte-americano, tinha um peso fundamental para indicar a direção de cada publicação. Segundo Rodrigues (2011, p. 54):

A "invasão britânica" contribuiu significativamente para imprimir nos quadrinhos norte-americanos características como uma maior preocupação com técnicas narrativas, enredos mais elaborados menos preocupados com linearidade, menos maniqueístas -, e a negação e/ou revisionismo do gênero super-herói. A negação e/ou revisionismo do gênero super-herói talvez tenha sido a mais radical característica desse grupo, visto que o super-herói é um elemento

\footnotetext{
sequential images into a meaningful experience of the passage of time. (...) In a comic book images are physically adjacent but separated by a blank space called the gutter. In a comic the movement through time is a function controlled by the viewer rather than the film editor. It takes time and a literal movement of the eye through space to read a comic book. Animation and filmmaking produce corporal illusions of movement, while comics place special emphasis on the viewer's conceptual sensibilities and ability to create closure. (...) Individual panels generally illustrate a moment in the narrative, but time is created in the gutter. "Here in the limbo of the gutter, human imagination takes two separate images and transforms them into a single idea."
} 
característico da sociedade norte-americana que quando transposto para outras culturas dificilmente obtém sucesso.

Alan Moore é frequentemente considerado como o precursor desse movimento que buscava inspirações políticas e filosóficas em um momento de desesperança, alimentado pela Guerra Fria (tema ao qual voltarei posteriormente) e pela paranoia nuclear coletiva advinda dela ${ }^{4}$. Ao lado do ilustrador também britânico Dave Gibbons, Moore criou sua visão sobre a sensação quase claustrofóbica que pairava no ar sobre a destruição iminente da humanidade. A década de 1980 trazia um sentimento de fim que se tornou o principal mote da narrativa de Watchmen, que mostra um mundo onde realmente existissem super-heróis sem quaisquer poderes especiais, sendo somente homens e mulheres encapuzados que portam ferramentas que os ajudam na luta contra o crime, como vigilantes acima da lei. Entre eles, somente um personagem se assemelha aos super-heróis tradicionais com poderes, o Dr. Manhattan, que será melhor analisado mais à frente.

\section{As histórias em quadrinhos e a Guerra Fria nos anos 1980}

A corrida armamentista nuclear entre Estados Unidos e União Soviética criou, no imaginário comum, uma sensação de insegurança apocalíptica. A inevitabilidade escatológica do confronto nuclear entre as duas grandes potências, uma capitalista e a outra comunista, foi retratada em diversas obras artísticas, e nas HQs não seria diferente. O sentimento de desconsolação global foi retratado em obras como Batman: The Dark Knight Returns (1986), Ronin (1987), Elektra: Assassin (1986), de Frank Miller; Black Orchid (1988) e The Sandman (1989) de Neil Gaiman; $V$ for Vendetta (1982), Batman: The Killing Joke (1988), Swamp Thing (1984) e Watchmen (1986), todas do próprio Moore ${ }^{5}$.

\footnotetext{
4 A vida e obra de Alan Moore foram muito exploradas por diversos autores internacionais e brasileiros. No entanto, recomendo a leitura da biografia escrita por PARKIN, Lance. Magic Words: The Extraordinary Life of Alan Moore. London: Aurum Press Ltd, 2013; e também o artigo de VERGUEIRO, Waldomiro. Alan Moore: Biografia e obra comentada. 2017. Disponível em: https://www.omelete.com.br/v-de-vinganca/alan-moore-biografia-e-obracomentada. Acesso em: 2 nov. 2017.
}

5 Para mais informações acerca da influência da Guerra Fria na produção cultural da época, conferir CZIZEWESKI, Grégori Michel. O fim está próximo: Poder, tensão e nostalgia na visão da Guerra Fria a partir de Watchmen. 2011. Disponível em: <https://repositorio.ufsc.br/xmlui/handle/123456789/95069>. Acesso em: 18 set. 2017. Algumas das imagens aqui referenciadas foram retiradas a partir da análise feita pelo autor e aprofundadas de acordo com 
Who watches the Watchmen: os espaços do tempo nos quadrinhos

Segundo Czizeweski (2011, p. 113), em Watchmen, a "iminência da Guerra Nuclear e do consequente fim do mundo é representada, inúmeras vezes e de diferentes maneiras, pela figura de relógios que mostram um horário cada vez mais próximo das 12 horas, que simbolicamente seria o Juízo Final." Assim, o pesar trazido pela iminente guerra nuclear arrebata homens e mulheres comuns que perderam a "razão":
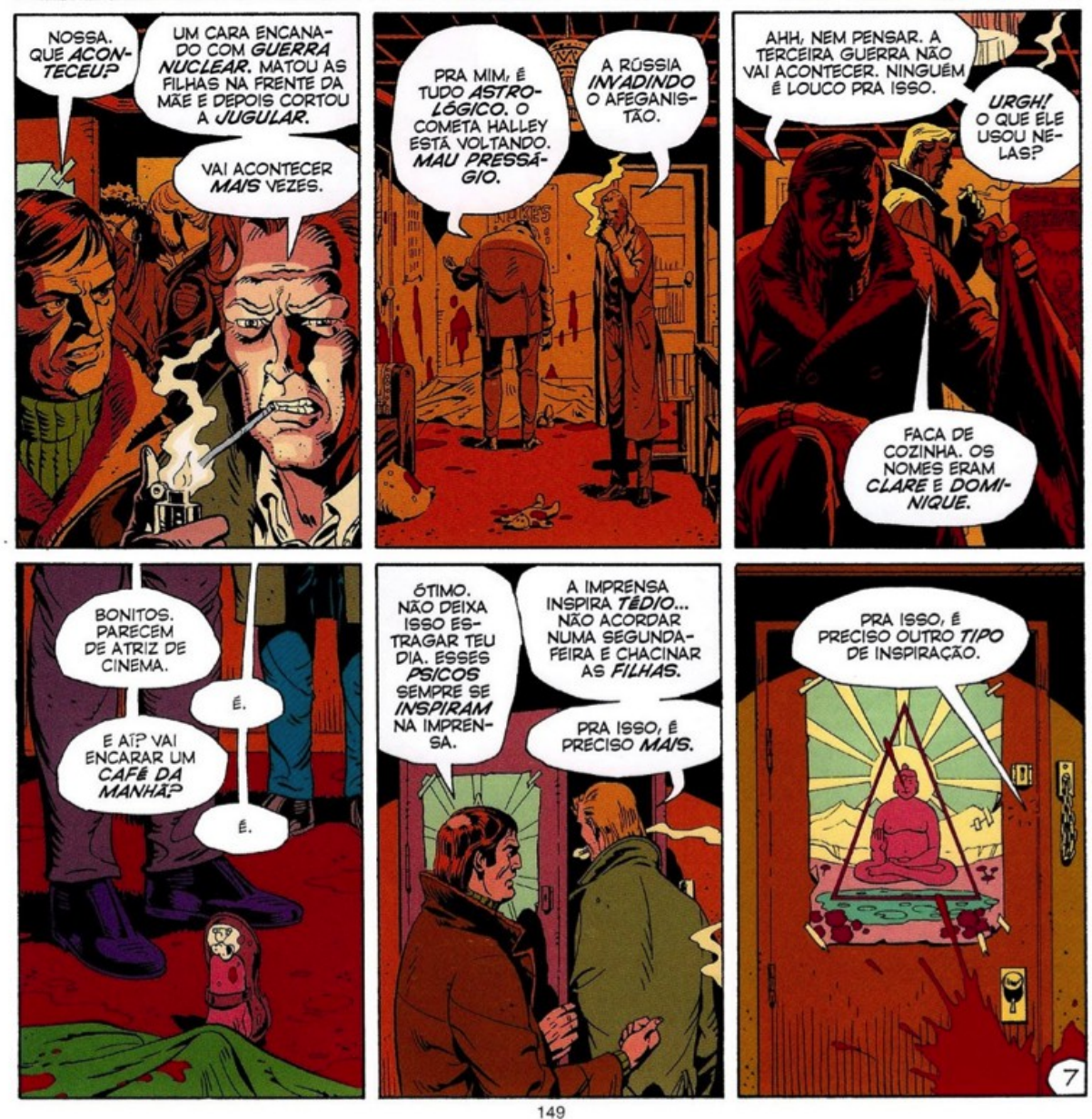

TM \& @ 2018 DC Comics

Imagem 2 - O medo da Guerra Nuclear afeta as pessoas

Os heróis também são afetados. Este é o caso do personagem Daniel Dreiberg, o Coruja, que vê seu relacionamento com Laurie / Espectral ameaçado pela possível Terceira

as intenções deste trabalho. 
Guerra Mundial. Na sequência de quadros abaixo, vemos como Daniel corre ao encontro de Laurie e como o corpo de ambos é obliterado por causa da explosão nuclear. Mas no último quadro vemos que tudo não passa de um pesadelo de Daniel, aterrorizado pelo sonho que tivera.
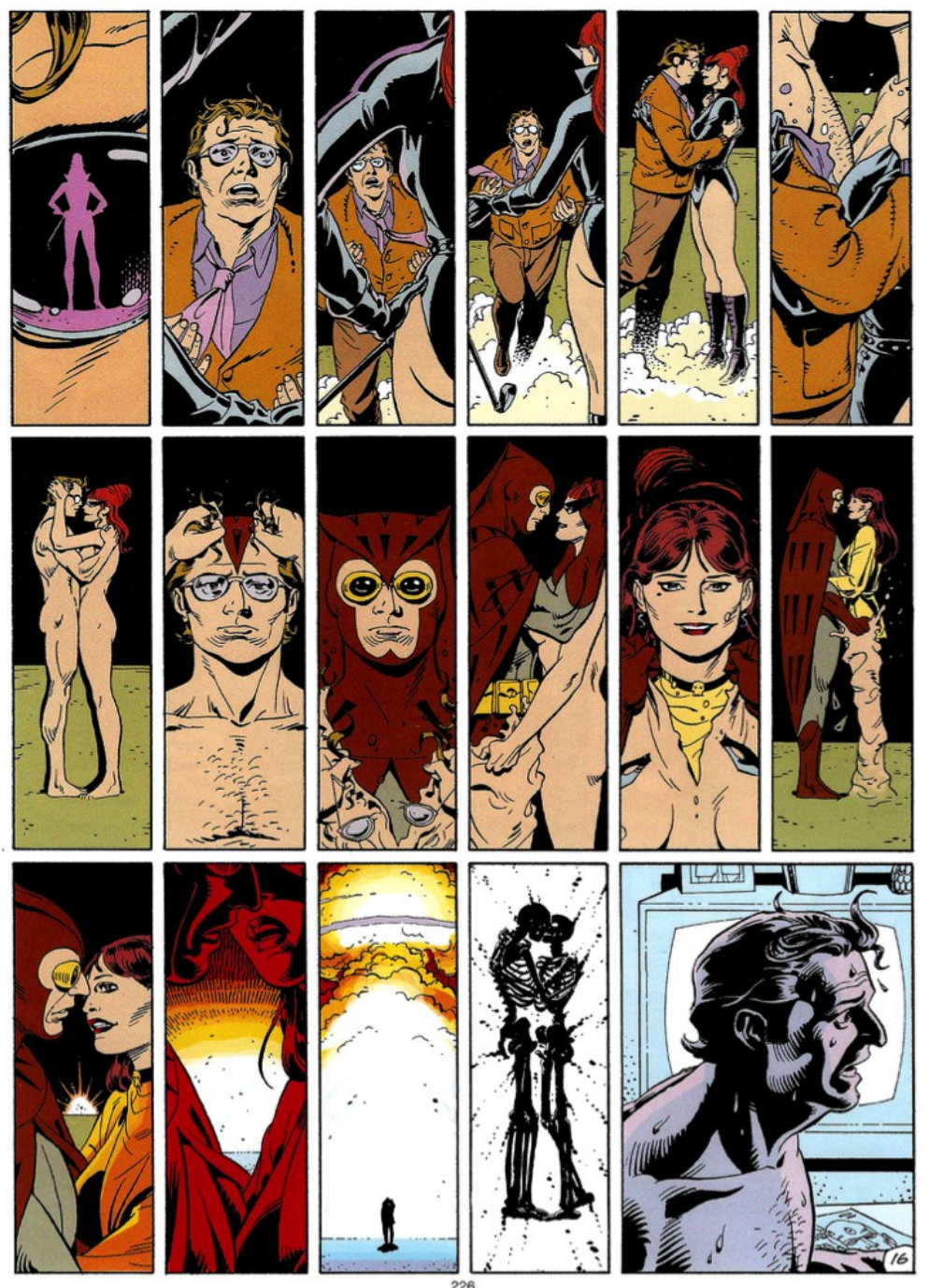

TM \& (c) 2018 DC Comics

Imagem 3 - Daniel Dreiberg / Coruja tem um pesadelo com a guerra nuclear

O fim parecia inevitável. Ao fim do capítulo 11 vemos a expressão das pessoas diante de uma explosão causada em Nova York, que matou milhares de pessoas na cidade, ilustrada na primeira página do capítulo 12. Mesmo que este assassinato em massa não tenha sido 


\section{dossiê}

Who watches the Watchmen: os espaços do tempo nos quadrinhos

resultado da guerra nuclear entre Estados Unidos e União Soviética é uma consequência dos planos de Ozymandias (alter-ego do famoso bilionário Adrian Veidt, que será explorado mais à frente), o medo retratado no rosto dos personagens mostra o resultado catastrófico construído no imaginário popular.
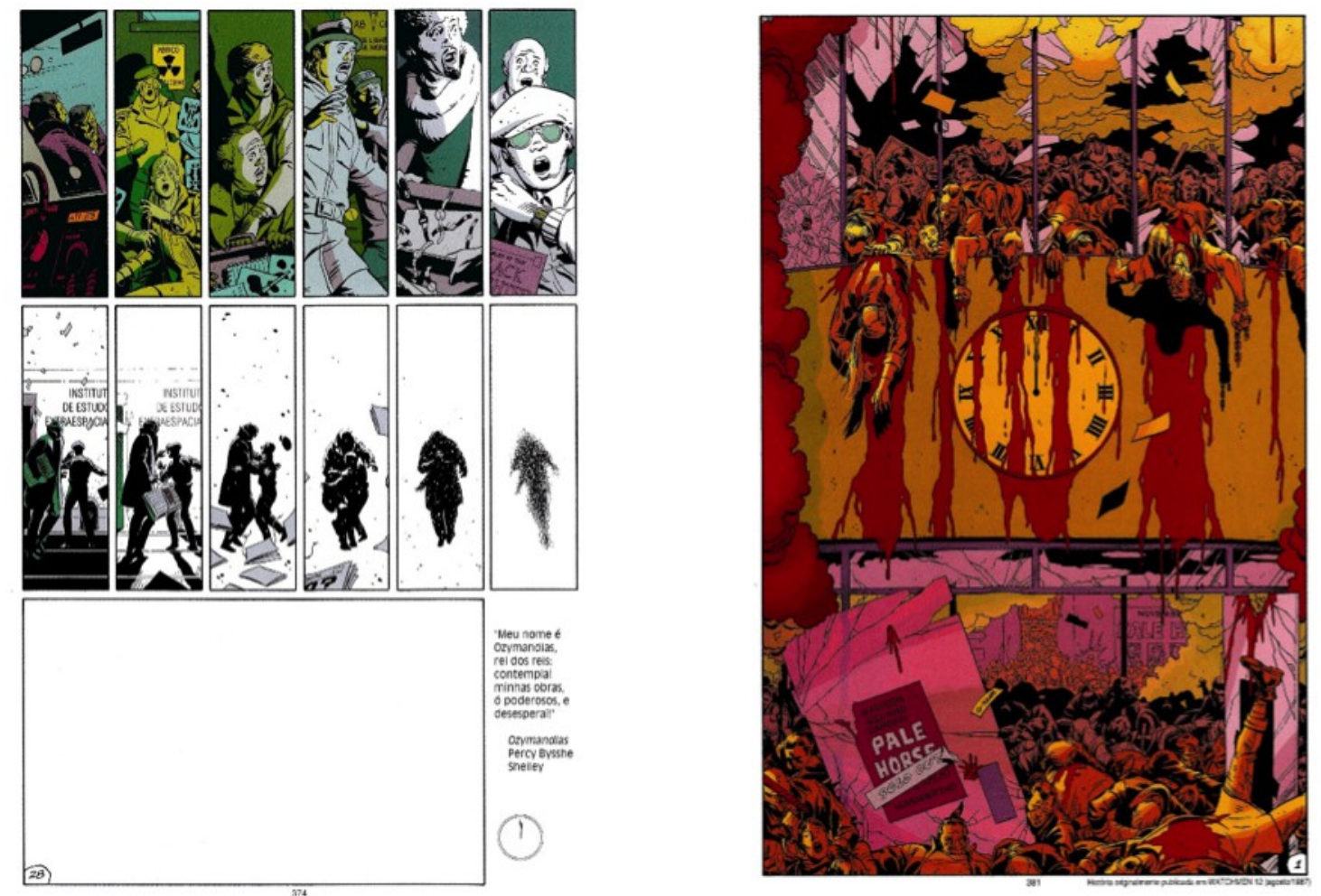

TM \& ( 2018 DC Comics

Imagem 4 - O fim nuclear traz a morte

A inevitabilidade do fim em Watchmen é retratada sempre pelo relógio, personagem fundamental na trama. Moore e Gibbons usam a referência do "Doomsday Clock" ou o Relógio do Juízo Final, um relógio simbólico criado em 1947 por físicos que compunham o Bulletin of Atomic Scientists da Universidade de Chicago, que definiu que quanto mais perto os ponteiros estivessem da hora 12 , mais perto estaria a humanidade de seu $\mathrm{fim}^{6}$. A guerra atômica seria o meio deste extermínio.

60 "Doomsday Clock" ou Relógio do Juízo Final é uma representação simbólica que mede o fim do mundo a partir das relações políticas, econômicas e sociais dos países. Para acompanhar a linha do tempo atual do "Doomsday Clock", conferir https://thebulletin.org/. 


\section{dossiê}

Roberta Quirino

Já no início da trama de Watchmen vemos uma manchete de jornal que mostra que o relógio marca cinco minutos para a meia-noite, o que enfatiza o peso da iminente guerra atômica mostrada na obra e seu alcance na mídia, de acordo com a medição do Relógio do Juízo Final.

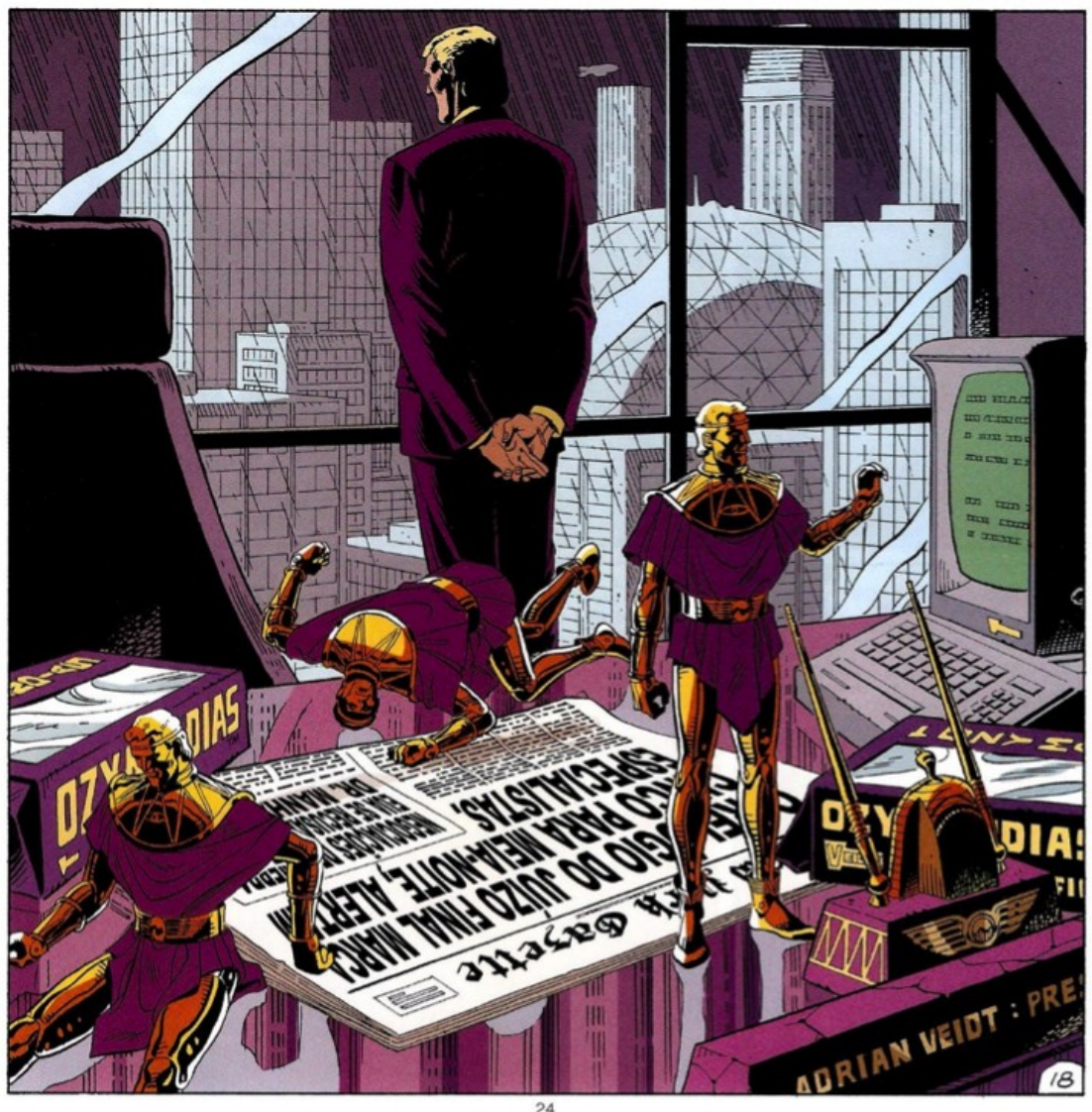

TM \& @ 2018 DC Comics

Imagem 5 - Adrian Veidt / Ozymandias e o alarde da mídia sobre o Relógio do Juízo Final

Além disso, as contracapas das doze edições estadunidenses também mostram o desfecho inevitável: a cada quadro a meia-noite está mais próxima e o sangue toma conta de cada página: 
Who watches the Watchmen: os espaços do tempo nos quadrinhos

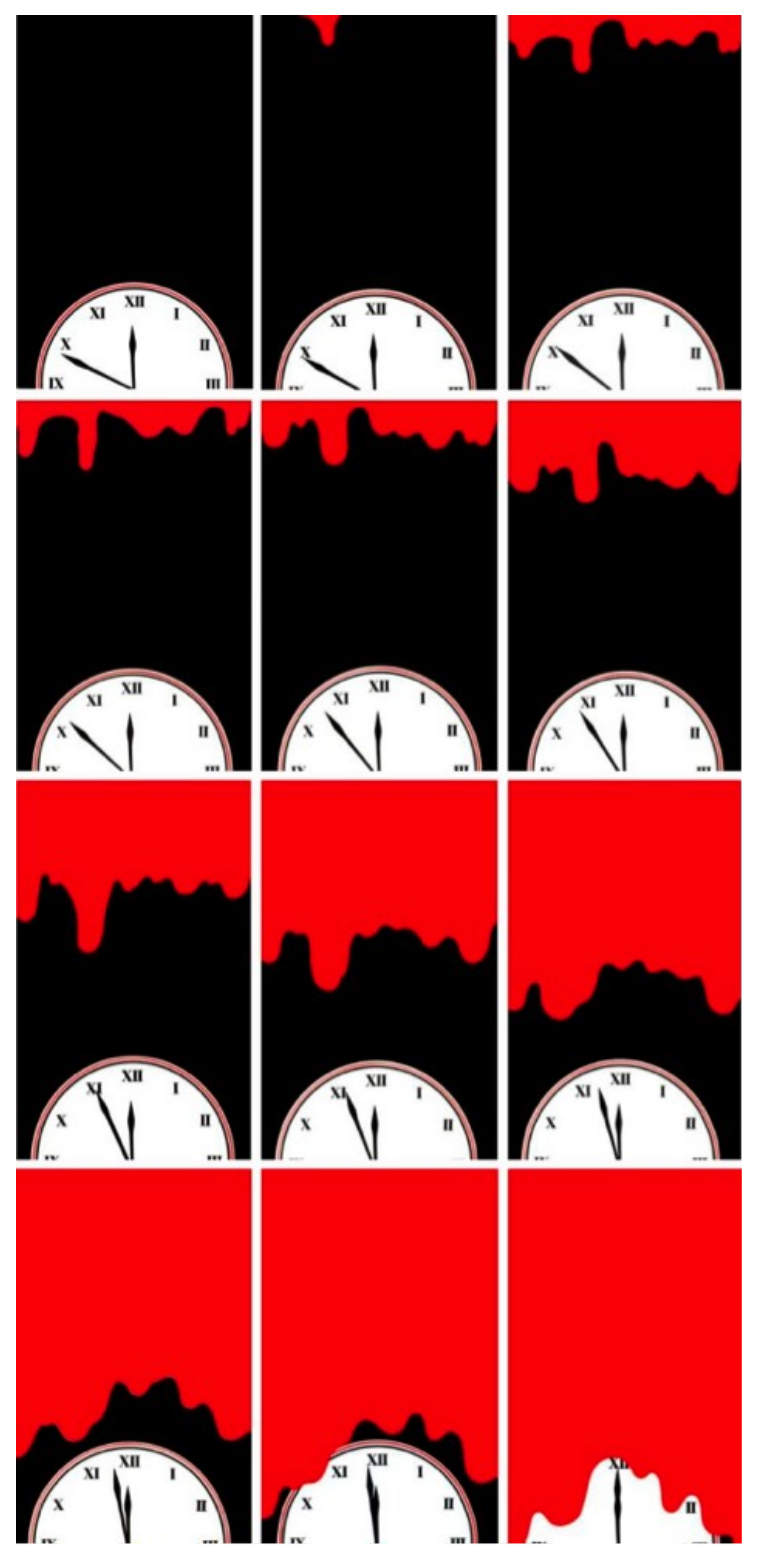

TM \& @ 2018 DC Comics

Imagem 6 - Quanto mais próximo da meia-noite, as páginas são tomadas pelo vermelho sangue.

Esta concepção escatológica do fim é retratada a partir do uso de termos como "apocalipse nuclear", "Relógio do Juízo Final”, "fim dos tempos". Recorrentes na obra inteira, eles mostram como a linguagem religiosa ${ }^{7}$ está intimamente ligada com esta ideia do fim atômico. Tal como mostra Marcelo Gleiser (2001, p. 10), “sempre existiu uma conexão entre a ciência, em particular a física e a astronomia, e a escatologia, o ramo da teologia que estuda

7 Para uma análise mais aprofundada sobre a visão teológica nos quadrinhos, recomendo a obra de REBLIN, luri Andréas. O Alienígena e o Menino. Jundiaí: Paco Editorial, 2015. 
questões relacionadas com o fim do tempo". Segundo Eliade (1992), a cosmogonia está presente em um ciclo de término e de renascimento que define a existência humana como um reflexo do passado mítico que, ao ser reeditado, melhora as novas perspectivas de presente da humanidade; os fins religiosos propõem, dessa forma, uma ideia de eternidade.

\section{A distopia de Watchmen: passagem do tempo e o Eterno Retorno}

O termo "distopia" pode ser definido como uma forma de "utopia" - que significa um lugar perfeito que não existe. Esta palavra ganhou este peso político de crítica à sociedade, a partir da obra Utopia de Thomas Morus, escrita no século XVI. A palavra "distopia" pode, portanto, ser considerada uma utopia ruim e sombria, sendo complementar a ela e não seu oposto.

Ambas as representações se encontram em Watchmen e se relacionam mutuamente. 0 universo criado por Alan Moore e Dave Gibbons é um universo distópico, posicionado no ano de 1985, onde a paranoia nuclear e a incerteza do espaço da tecnologia na sociedade colocam em xeque o andamento até então conhecido do mundo. A descrença sobre o futuro e o papel da ciência que desenvolveu a bomba atômica potencializou uma das angústias das pessoas em relação a uma não-existência do futuro.

A utopia, enquanto conceito, pode significar não propriamente um lugar, mas também um sentimento de expectativas frustradas acerca do futuro. Esse tipo de elaboração sobre o porvir é mostrado por meio de uma crítica do momento presente daquela obra. Em Watchmen, seus autores fazem uma leitura crítica sobre o presente em que vivem e como ele não mostra um bom amanhã ou sequer a existência dele. A definição dada por Rüsen (2007, p. 136-37) é bastante expansiva e vai além da ideia de utopia enquanto gênero literário:

Para mim há algo mais fundamental: um modo do manejo interpretativo da interpretação de circunstâncias dadas da vida. O pensamento utópico definese pela negação das circunstâncias da vida. Ele articula carências, na expectativa de circunstâncias de vida nas quais desaparecem as restrições à satisfação dessas carências. A constituição utópica de sentido pressupõe que 
Who watches the Watchmen: os espaços do tempo nos quadrinhos

as condições atuais do agir são irreais e que é possível imaginar outras condições totalmente adversas.

A partir da visão distópica que Moore e Gibbons têm - ou, pelo menos, que elaboram em sua obra - sobre o mundo que constroem, eles contrapõem essa visão a de Ozymandias que, tido como o homem mais inteligente do mundo e com um porte físico impecável, articula um plano para atingir a utopia de paz a que o mundo se destinará a partir da união de todas as nações e o fim dos conflitos entre elas. Ao subestimar a possibilidade da humanidade evitar a guerra nuclear, Ozymandias se coloca à frente desta lição, que deve ser ensinada aos seres humanos. Assume para si este "fardo" de matar milhares para salvar bilhões de sua extinção nesta corrida tresloucada em busca da superioridade bélica e nuclear; o seu fim justificaria os meios. O pseudônimo de Veidt não é escolhido por acaso. O capítulo XI termina com um trecho do poema homônimo de Percy Bysshe Shelley, o que ilustra bem a justificativa dos atos do personagem em busca deste "Bem maior", que justificaria a postura totalitária de Veidt: “Meu nome é Ozymandias, rei dos reis: contemplai minha obra, ó poderosos, e desesperai" ${ }^{8}$. Nos quadros abaixo podemos perceber o tom messiânico do discurso de Veidt: percebendo como o mundo sucumbiria diante de tantos conflitos, ele decide acabar com o medo do fim gerado pela Guerra Fria; decide sacrificar alguns milhares para "salvar" bilhões de seres humanos.

8 Sobre o poema de Shelley: MOORE, Alan; GIBBONS, Dave. Watchmen. Barueri, SP: Panini Books, 2011, p. 374. O conceito de "Bem Maior" é bastante explorado em TEIXEIRA, Níncia Cecília Ribas Borges; CORREA, Wyllian Eduardo de Souza. Watchmen e o discurso distópico do "Bem Maior". Fênix: Revista de História e Estudos Culturais, Uberlândia, v. 6, n. 2, p.1-21, abr-jun. 2009. Disponível em:

< http://www.revistafenix.pro.br/PDF19/Artigo_02_Nincia_Cecilia_Ribas.pdf>. Acesso em: 18 set. 2017. 


\section{dossiê}

Roberta Quirino
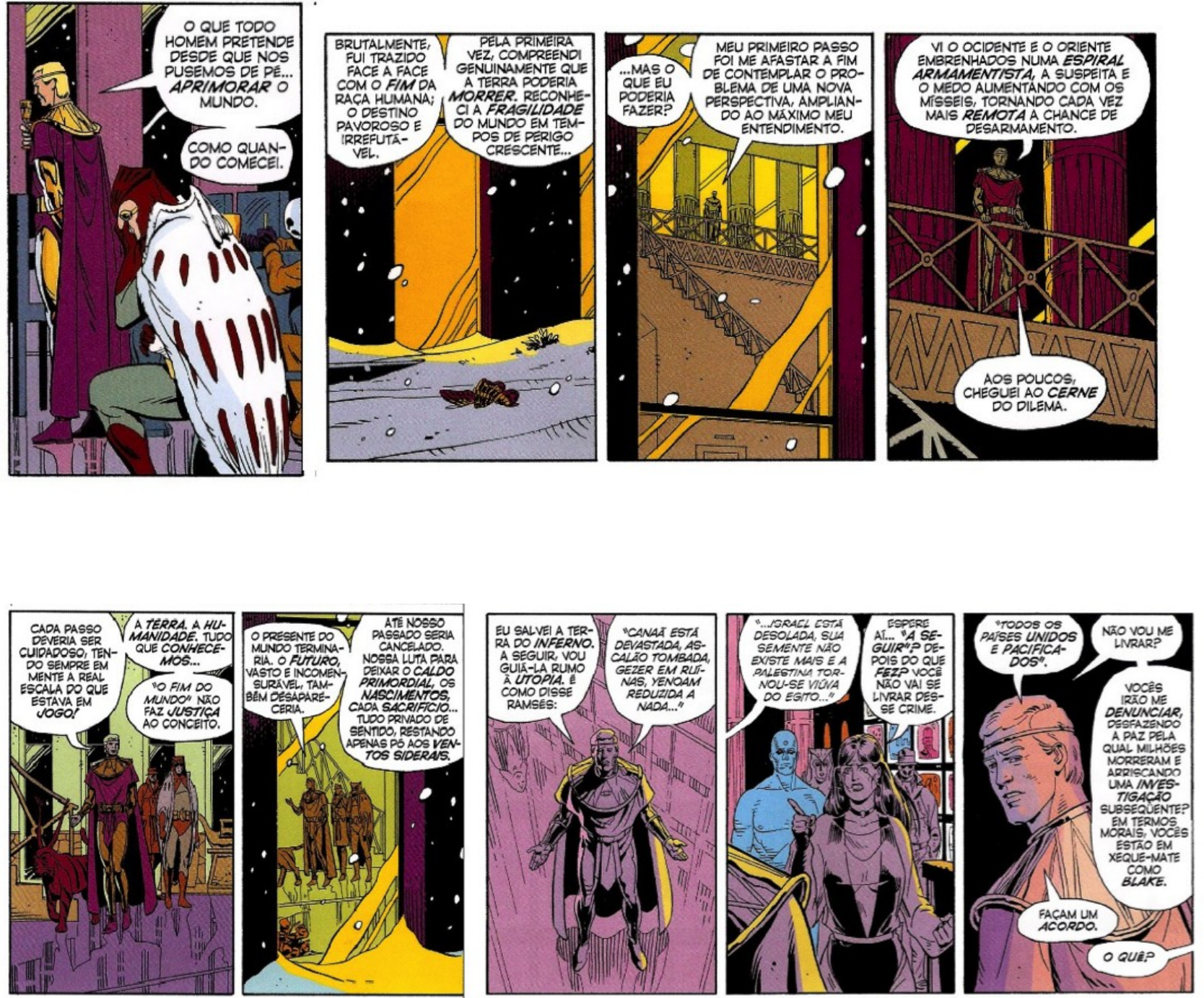

TM \& (c) 2018 DC Comics

Imagem 7 - Os heróis descobrem os planos de Ozymandias

Nos quadros seguintes, os outros heróis que antes condenavam o plano de Ozymandias acabam se tornando seus cúmplices, e ratificam os meios para se chegar ao bem maior de unidade e paz mundial.

A ligação entre Dr. Manhattan e Ozymandias é reforçada nas últimas páginas da obra, onde ambos assumem seus fardos pessoais nesta busca de algo maior: Veidt defendendo suas artimanhas em busca de um futuro possível e positivo e Dr. Manhattan que recupera 


\section{dossiê}

Who watches the Watchmen: os espaços do tempo nos quadrinhos

seu interesse pela vida humana, mas que decide rumar para uma "galáxia menos complicada". Ele abandona a Terra e os terráqueos por não se interessar por seus dramas.
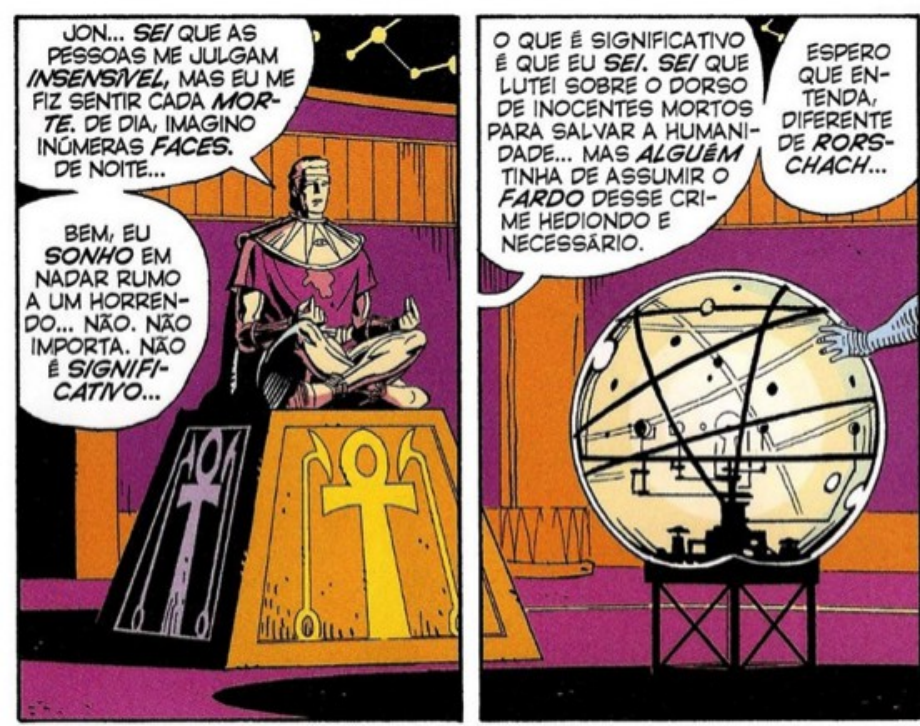

TM \& @ 2018 DC Comics

Imagem 8 - A ligação entre Dr. Manhattan e Ozymandias

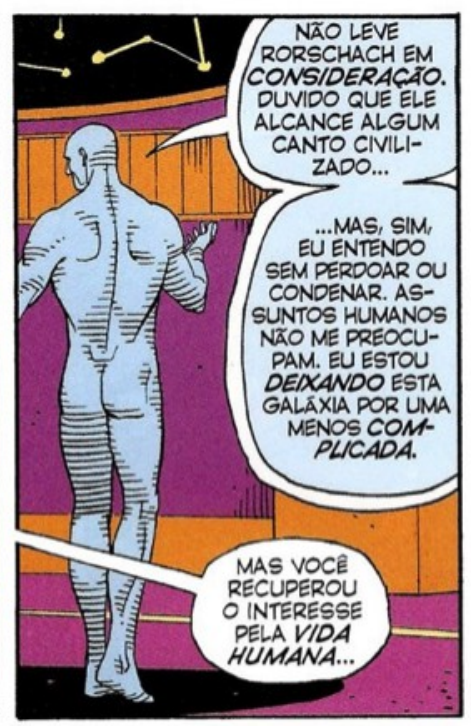

Moore e Gibbons mostram, portanto, uma possibilidade pela qual conceitos de "utopia" e "distopia" se relacionam reciprocamente. O futuro negativo e ingovernável apresentado em toda a trama teria uma nova página em aberto a partir das ações de Ozymandias. A pergunta que se mostra, implicitamente, ao final da obra é: o drama heroico de Veidt seria suficiente para justificar o assassinato de milhares de inocentes em busca de sua utopia futura? Moore e tampouco Gibbons respondem à questão, mantendo a ambiguidade da construção dos personagens e mostrando que todos eles são compostos de tons que escapam do maniqueísmo bem/mal.

Para exemplificar tal ambiguidade, podemos recorrer ao conceito de Eterno Retorno de Friederich Nietzsche. A filosofia do pensador alemão tem, em seu niilismo, um debate sobre a superação do ser humano de dogmas ou correntes morais e ideológicas que o impedem de atingir uma vida plena. A partir desta conceituação, é possível entender como a noção deste eterno retorno, que também pode ser religioso e ancestral e que não diz respeito só a 
Nietzsche, se percebe por meio do Dr. Manhattan, único personagem heroico com uma visão bastante interessante sobre o passar do tempo.

O eterno retorno para Nietzsche não é uma teoria sobre o tempo, mas sim como ele é percebido. Kurowsky (2016, p. 19) coloca bem o significado deste conceito:

Segundo Nietzsche, o eterno retorno seria uma nova forma de contemplar a realidade, uma nova perspectiva; basicamente, o eterno retorno seria a estratégia ideológica do super-homem, o Übermensch, o homem que abandona o niilismo em prol de um estilo de vida livre, desprovido de muletas metafísicas, como seria o caso da religião ou de filosofias que valorizam qualquer tipo de mundo que não seja o real (...) Para Nietzsche, niilista é aquele que deixa de viver a vida em prol de algum valor moral ou recompensa metafísica.

Um dos aspectos do eterno retorno diz respeito aos ciclos repetitivos da vida; estamos sempre presos a um número limitado de fatos que se repetem no passado, ocorrem no presente e se repetirão no futuro. Atrelado a este conceito, está a vontade de potência que move o indivíduo nesta busca pela plena vivência; o eterno retorno é o direcionamento desta vontade de potência e da maneira como ela deve ser aplicada.

Os superpoderes do Dr. Manhattan - fundamentais para entender o processo de mutação e maturidade pelos quais o personagem passa - foram obtidos depois de um acidente atômico sofrido por ele quando era físico nuclear. Ao ficar preso na câmara de testes, seu corpo é obliterado quando o experimento é iniciado automaticamente. Preso, ele encara a incapacidade dos outros cientistas de libertá-lo e de livrá-lo da morte.

Devido ao contato com a energia nuclear, ele consegue reorganizar os átomos e cria uma nova casca, um novo corpo para habitar. Nasce o Dr. Manhattan, o "super-homem", usado como ferramenta legitimadora e alegórica da supremacia do país sobre o mundo. 

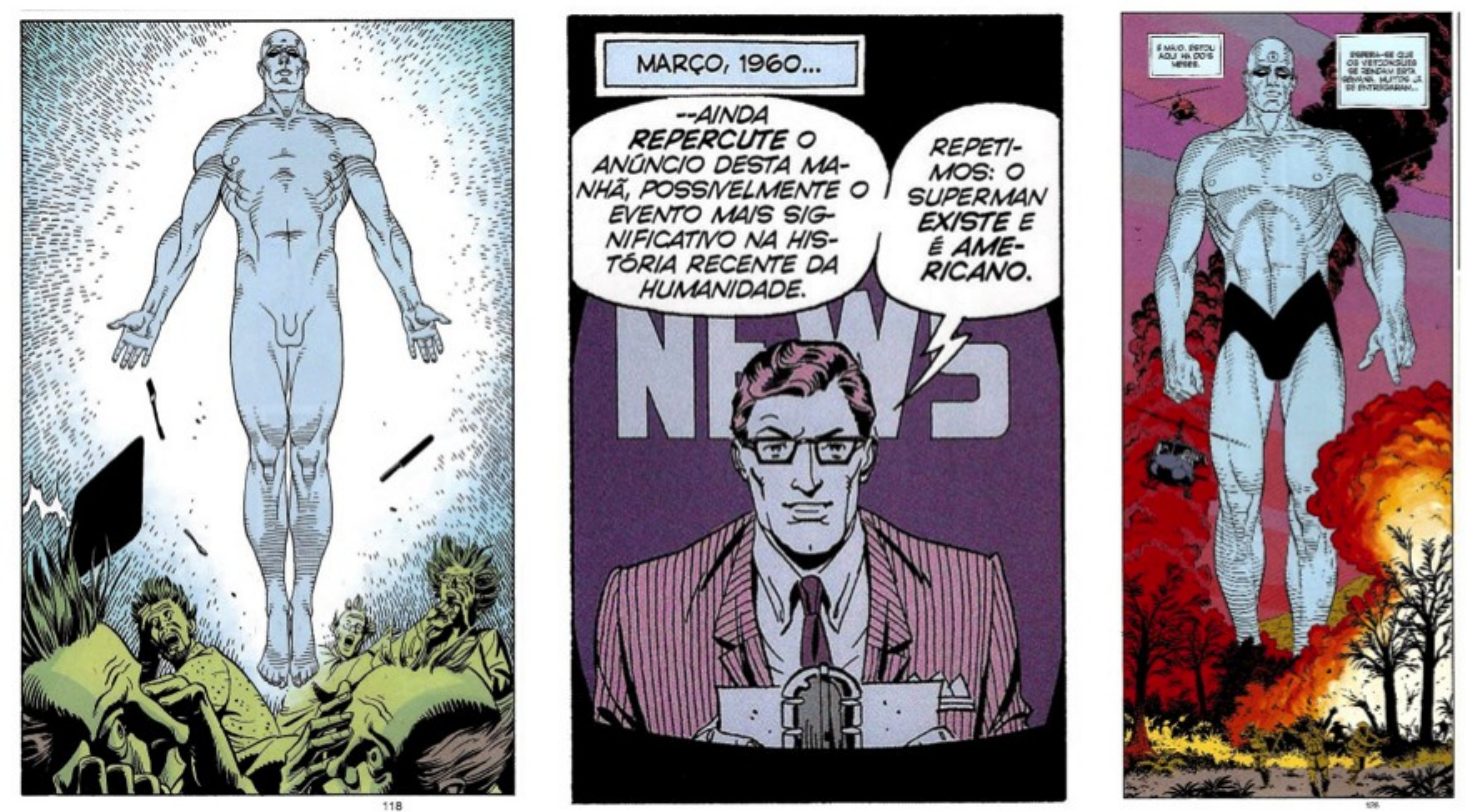

TM \& @ 2018 DC Comics

Imagem 9 - Dr. Manhattan é o super-homem estadunidense

Esta reorganização atômica do próprio corpo é só um dos atributos "divinos" do personagem. Tendo uma consciência cada vez maior de suas habilidades e aprendendo a lidar com elas, Dr. Manhattan também começa a entender o tempo de maneira diferente: ele é simultâneo; passado, presente e futuro acontecem ao mesmo tempo.

Quanto maior o controle do personagem sobre estes poderes, maior é o afastamento dele dos seres humanos e de sua própria humanidade. O desinteresse sobre os valores morais da sociedade e, consequentemente, seus conflitos, se mostra evidente no decorrer da história. Abandonar a Terra e ir para Marte, longe de toda a insignificância humana se revela o mais interessante para este super-humano. 


\section{dossiê |e}

Roberta Quirino
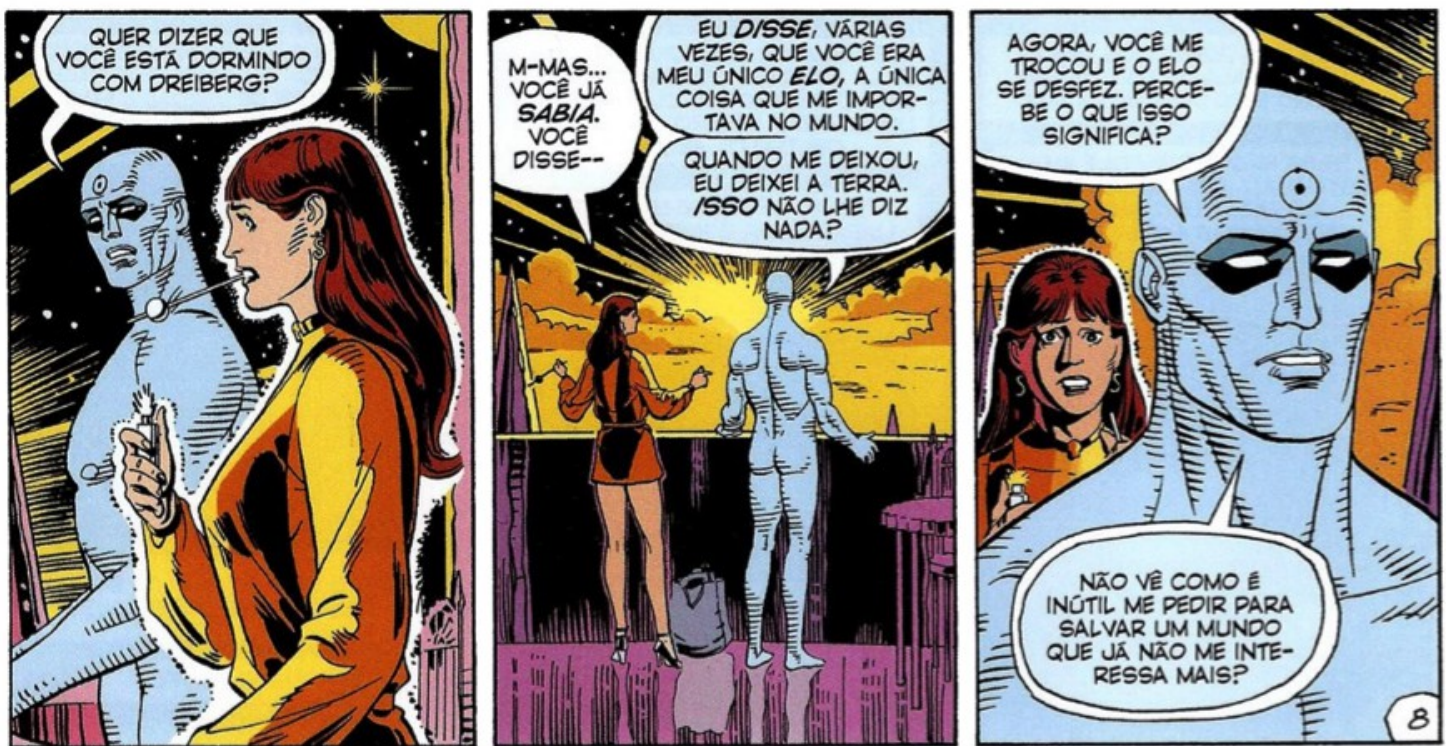

286
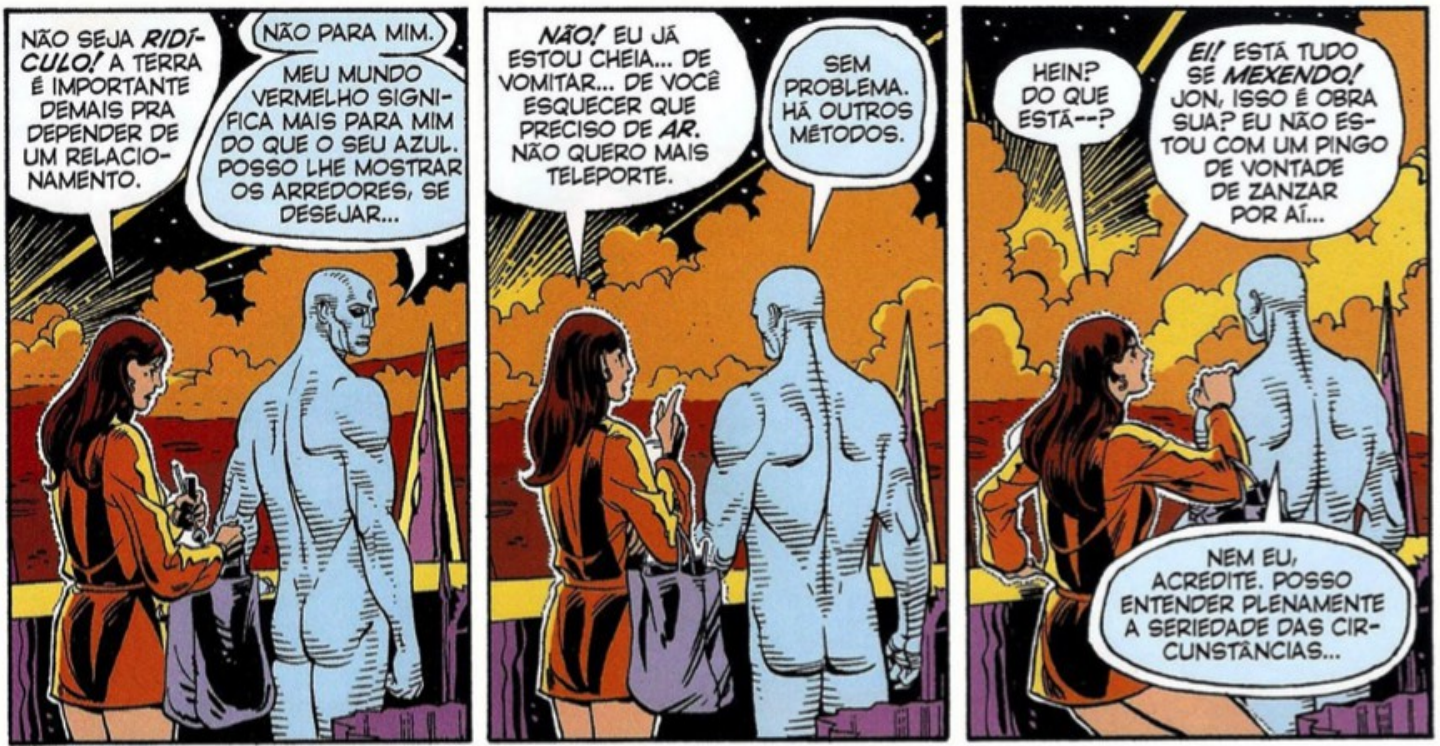

TM \& @ 2018 DC Comics

Imagem 10 - Dr. Manhattan demonstra seu desinteresse pela raça humana quando sua relação com Laurie é desfeita

No entanto, como mostra a imagem acima, em algum momento - a partir da vontade de potência assinalada por Ozymandias em busca do seu "Bem Maior" - ele recupera o interesse pela vida humana, mas escolhe não lidar com ela. A complexidade da humanidade afasta o Dr. Manhattan e até o induz a criar algo. 
Who watches the Watchmen: os espaços do tempo nos quadrinhos

A percepção do tempo como evento unificado é onde o conceito de eterno retorno de Nietzsche se encaixa na narrativa de Osterman. Em vários momentos da graphic novel vemos o personagem tentando compreender essa sua nova visão de tempo e tentando encontrar seu lugar a partir da singularidade que o rodeia. As sarjetas, ou seja, o espaço vazio entre os quadros que conclui, na mente do leitor, a ação iniciada pelo autor, são fundamentais para entender a sincronia do tempo para o personagem.
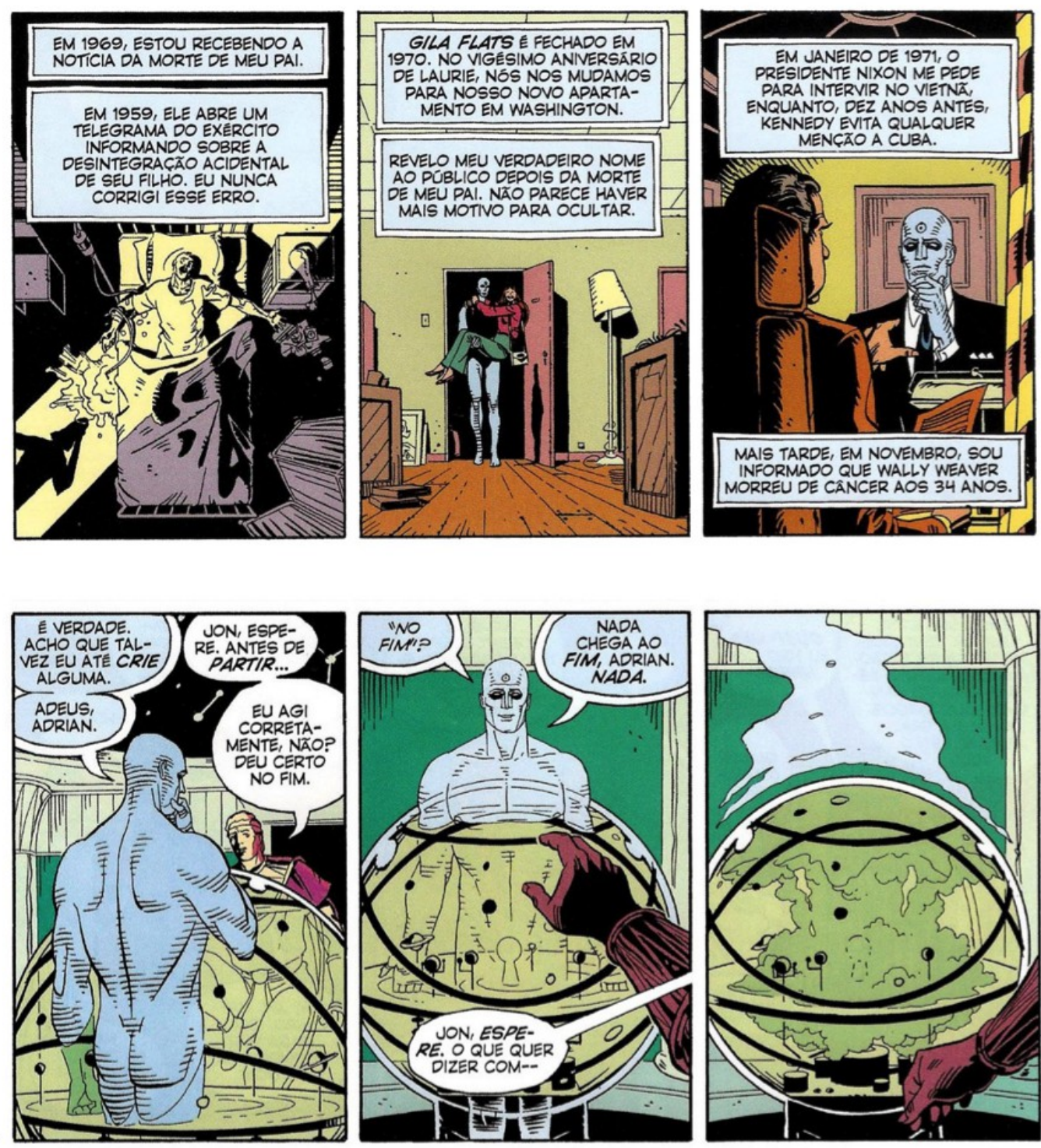

TM \& (c) 2018 DC Comics

Imagem 11 - A sincronia do tempo para Dr. Manhattan 
Roberta Quirino

Essa percepção temporal do personagem, que vive múltiplos tempos ao mesmo tempo, impede, no entanto, a sua vontade de potência para agir nos conflitos humanos. Ao compreender o tempo como algo simultâneo, ele se mostra incapaz de tomar qualquer atitude e se apresenta como um observador apático das ações do homem neste embate entre as potências que controlam as tecnologias nucleares. Como assinala Kurowsky (2016, p. 40):

Dr. Manhattan incorpora todos esses aspectos ao utilizar o eterno retorno como negação de si mesmo. Ele vive o passado, o presente e o futuro como uma unidade, conhece os ecos de tudo que faz, a repercussão de suas medidas, e justamente por isso é incapaz de viver plenamente. $O$ eterno retorno resulta em exaustão, em distanciamento.

Voltemos ao relógio e como ele se mostra como um condicionante da personalidade do Dr. Manhattan. Na adolescência, o então jovem Jon Osterman, é apresentado tentando consertar um relógio desmontado. No entanto, ele é surpreendido por seu pai que, atordoado com a notícia sobre o lançamento das bombas atômicas em Hiroshima e Nagasaki, mostra ao filho como a noção de tempo será mudada para sempre, já que a velha concepção de um tempo infinito, representada pelo tilintar dos ponteiros do relógio, é abandonada pela ideia de um tempo finito e frágil a partir da realidade da energia nuclear. O jovem Osterman é então obrigado pelo pai a estudar física nuclear, área de conhecimento considerada o "futuro" da humanidade. O papel do relojoeiro não se encaixa neste futuro de paranoia nuclear, já que o seu papel de manutenção de um tempo cíclico e contínuo já não vale mais em tempos que prenunciam um inevitável fim. 


\section{dossiê |e}

Who watches the Watchmen: os espaços do tempo nos quadrinhos
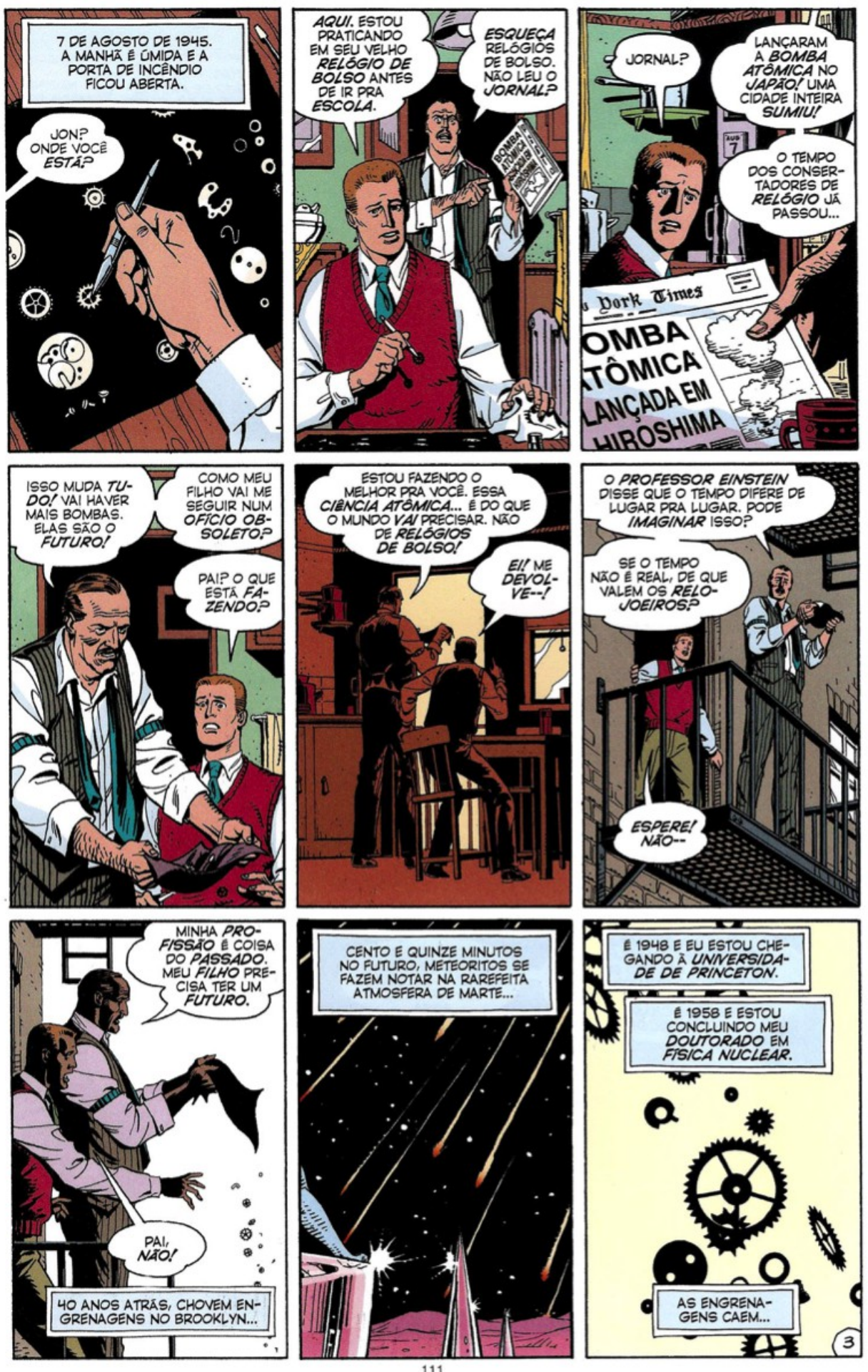

TM \& @ 2018 DC Comics

Imagem 12 - O tempo do relógio não é o mesmo tempo da iminente guerra nuclear 
Roberta Quirino

\section{Considerações finais}

O tempo, enquanto integrante da linguagem dos quadrinhos, se mostra uma ferramenta fundamental para que a narrativa transcorra. Mais do que um espaço entre os quadros, as sarjetas são também instrumentos e fontes de representações que atuam diretamente na passagem do tempo da história contada. Sua linearidade se quebra e passado, presente e futuro se complementam na mesma página.

A paranoia coletiva de uma guerra nuclear iminente que pairava ainda na década de 1980 por causa da manutenção da Guerra Fria entre Estados Unidos e sua cruzada capitalista, e União Soviética, em sua cruzada comunista, influenciou a produção das histórias em quadrinhos para uma nova fase de adaptação e maturidade enquanto arte e literatura. Já nos anos 1980, as HQs deixam de ser voltadas para o público infanto-juvenil e se mostram como mais uma forma de expressão artística acerca da interpretação de mundo que roteiristas e ilustradores têm sobre a sensação de insegurança da época. A ascensão das graphic novels mostra essa sensação quase claustrofóbica que é transposta à toda esta produção cultural.

E m Watchmen, isso é mostrado de maneira medular. Alan Moore e Dave Gibbons colocam sua interpretação de um futuro que promete ser sombrio ou inexistente, caso as ameaças nucleares se concretizem. A relação com o rápido avanço da tecnologia também é mostrada com um receio sobre até que ponto estas técnicas que se mostram predominantes podem influenciar na vida em sociedade.

O conceito de eterno retorno é abordado na persona do Dr. Manhattan como um homem que quebra a ideia fragmentada de tempo que é passada à humanidade, mas que, se mostra como um mero observador, quase como um efeito reverso da teoria de Nietzsche: só a realidade imediata lhe importa e, independente do resultado catastrófico que pode se mostrar para os seres humanos, o universo continuará seu curso; a ideia quase divina do quanto o homem é supostamente especial e único se quebra totalmente. 
Who watches the Watchmen: os espaços do tempo nos quadrinhos

A vontade de potência atrelada ao eterno retorno é apresentada em outro personagem que, mesmo sem ter esta visão de unicidade do tempo, não se deixa corromper por valores metafísicos ou religiosos para atingir seus objetivos: Ozymandias não mede esforços para salvar a raça humana da extinção; toma para si um fardo de pastor das ovelhas perdidas, corrompidas e insignificantes que habitam este planeta. Para construir um novo espírito de união entre os homens, ele não se importa em assassinar milhares e os outros heróis que se calam diante dos planos megalomaníacos de Ozymandias, se mostram cúmplices em busca deste "Bem Maior".

Watchmen nos mostra uma série de nuances dos personagens e das situações apresentadas e foge do maniqueísmo habitual construído na Guerra Fria, ao construir uma história complexa que aborda diversos conceitos filosóficos, sociais, políticos, econômicos e culturais. É uma obra fértil de análises e interpretações e dialoga não só com as obras produzidas na década de 1980, mas também se tornou referência para materiais elaborados até hoje. Sua influência vai além da produção no campo da história em quadrinhos e atinge outros campos de conhecimento e pesquisa ao se tornar objeto de análise como nos trabalhos apresentados neste artigo. Vinda de uma época onde as graphic novels foram um ponto de virada na produção quadrinística, não é exagero afirmar que Watchmen deixou sua marca como uma das obras que se tornaram referência no mundo dos quadrinhos. Mais do que simplesmente contar uma história, a obra de Moore e Gibbons mostra como a crítica sobre a sociedade, representada em seus vários tempos históricos, também cabe em formatos, cores e balões.

\section{Fonte:}

MOORE, Alan; GIBBONS, Dave. Watchmen. Barueri, SP: Panini Books, 2011.

\section{Referências bibliográficas:}

BARNES, David. Time in the Gutter: Temporal Structures in Watchmen. Kronoscope, [s.l.], v. 9, n. 1, p.51-60, 1 maio 2009. Brill Academic Publishers. 
CZIZEWESKI, Grégori Michel. O fim está próximo: Poder, tensão e nostalgia na visão da Guerra Fria a partir de Watchmen. 2011. 150 f. Dissertação (Mestrado) - Curso de História, Universidade Federal de Santa Catarina, Florianópolis, 2011.

EISNER, Will. Quadrinhos e arte sequencial. São Paulo: Martins Fontes: 2000.

ELIADE, Mircea. O Sagrado e o Profano: A essência das religiões. São Paulo: Martins Fontes, 1992.

GLEISER, Marcelo. O fim da Terra e do Céu: O Apocalipse na ciência e na religião. São Paulo: Companhia das Letras, 2001.

KUROWSKY, Kleber. Os vários lados da joia: o tempo narrativo e o eterno retorno em Watchmen. 2016. 51 f. TCC (Graduação) - Curso de Letras, Universidade Federal de Santa Catarina, Florianópolis, 2016.

McCLOUD, Scott. Desvendando os quadrinhos. São Paulo: Mbooks do Brasil, 2005.

PARKIN, Lance. Magic Words: The Extraordinary Life of Alan Moore. London: Aurum Press Ltd, 2013.

POSTEMA, Barbara. Estrutura narrativa nos quadrinhos. Construindo sentido a partir de fragmentos. São Paulo: Peirópolis, 2018.

REBLIN, Iuri Andréas. O Alienígena e o Menino. Jundiaí: Paco Editorial, 2015.

RODRIGUES, Márcio dos Santos. Representações políticas da Guerra Fria: as histórias em quadrinhos de Alan Moore na década de 1980. 2011.

RÜSEN, Jörn. História viva: teoria da história: formas e funções do conhecimento histórico. Brasília: Editora Unb, 2007.

SABIN, Roger. Adult Comics: An Introduction. New accents. London and New York: Routledge, 1993.

TEIXEIRA, Níncia Cecília Ribas Borges; CORREA, Wyllian Eduardo de Souza. Watchmen e o discurso distópico do "Bem Maior". Fênix: Revista de História e Estudos Culturais, Uberlândia, v. 6, n. 2, p.1-21, abr-jun. 2009.

VARGAS, Alexandre Linck. A invenção dos quadrinhos: teoria e crítica da sarjeta. 2015. $320 \mathrm{f}$. Tese (Doutorado) - Curso de Literatura, Universidade Federal de Santa Catarina, Santa Catarina, 2015.

VERGUEIRO, Waldomiro. Alan Moore: Biografia e obra comentada. 2017. Disponível em: <https://omelete.uol.com.br/quadrinhos/artigo/alan-moore-biografia-e-obra-comentada/>.

WHITE, M. D. Watchmen e a filosofia: um teste de Rorschach. São Paulo: Madras, 2009.

WOLF-MEYER, Matthew. The World Ozymandias Made: Utopias in the Superhero Comic, Subculture, and the Conservation of Difference. Journal Of Popular Culture, Michigan, v. 36, n. 3, p.497-517, mar. 2003. 


\section{dossiê}

Who watches the Watchmen: os espaços do tempo nos quadrinhos

\section{Imagens}

Imagem 1 - McCLOUD: 2005, p. 66.

Imagem 2 - MOORE \& GIBBONS: 2011, p. 149.

Imagem 3 - MOORE \& GIBBONS: 2011, p. 226.

Imagem 4 - MOORE \& GIBBONS: 2011, p. 374 e 381.

Imagem 5 - MOORE \& GIBBONS: 2011, p. 24.

Imagem 6 - MOORE \& GIBBONS: 2011, p. 39, 73, 107, 141, 175, 209, 243, 277, 311, 345, 379, 413.

Imagem 7 - MOORE \& GIBBONS: 2011, p. 364, 367, 368, 400.

Imagem 8 - MOORE \& GIBBONS: 2011, p. 407.

Imagem 9 - MOORE \& GIBBONS: 2011, p. 118, 121, 128.

Imagem 10 - MOORE \& GIBBONS: 2011, p. 286 e 287.

Imagem 11 - MOORE \& GIBBONS: 2011, p. 127, 407.

Imagem 12 - MOORE \& GIBBONS: 2011, p. 111. 